\title{
ANALYSIS OF AUTONOMY FACTOR OF ENTREPRENEURSHIP INTENTION WITH REFERENCE TO STUDENTS OF SELECTED UNIVERSITIES OF NORTH-INDIA
}

\author{
Tusshar Mahajan $^{1 *}$, Vikas Arora ${ }^{2}$ \\ ${ }^{1}$ Institute of Management Studies, Ghaziabad, U.P., India \\ ${ }^{2}$ SUNSHINE Group of Institutions, Rajkot, Gujarat, India \\ *Corresponding author; Email: tushar.mahajan8@gmail.com
}

\begin{abstract}
Entrepreneurship leads to economic growth and social development. Entrepreneurship is a risk-taking activity which needs dedication and focused approach. In case of students, starting a new venture is not an easy task, due to inclusion of high risk and uncertain future. There are many factors that trigger Entrepreneurship Intention of students; Autonomy is one such factor. The present study analyzed autonomy factor of entrepreneurship intentions of students with reference to North-India region. Students were found to have more inclination towards entrepreneurship with respect to autonomy factor. The study implied that NonMetropolitan area students and especially Non-Metropolitan female students are more inclined towards entrepreneurship due to aspiration of autonomy.
\end{abstract}

Keywords: Entrepreneurship, entrepreneurship intention, autonomy, North-India.

\section{Introduction}

Over the past few decades, entrepreneurship has become a buzzword. It plays a crucial role for economic progress, employment generation and social development. Entrepreneurship not only leads to individual development but for the development of society as well. Entrepreneurship is a vigorous process leading to wealth creation, for which entrepreneurs put efforts, take risk and in turn offer product(s) or service(s) with value addition. Success of entrepreneurship depends upon vision, innovativeness and risk taking. Now youths are more inclined towards entrepreneurship. Young people can bring drastic change through entrepreneurship; hence young entrepreneurs should be motivated to start their own venture and hence to contribute to the national economy. Kuratko and Hodgetts (2004) showed that entrepreneurship involves employment opportunities creation. Henry (2003) reported that many business graduates after completing their studies are unable to get a job, so the education must equip the students with entrepreneurship skills to start their own business.

This research study focused on identifying factors affecting Entrepreneurship Intentions of students of selected universities of the North-India region. Specifically, it is an attempt to examine the effect of autonomy factor on entrepreneurship intentions of students along with effect of specific demographic variables on autonomy factor of entrepreneurship intentions.
Various researchers studied demographic factors affecting the Entrepreneurship Intention. In a research study, it was found that demographic factors like income and gender affect the innovative attitude of arts and business students (Gibson \& Gibson, 2010). Friedman and Triburelle (2009) showed that genderrole orientation is a predominant forecaster of entrepreneurship intentions of MBA students. In this regard, they concluded that students with masculine orientation exhibited more entrepreneurship intention. Women and men have conventionally expected different characteristic roles in context of society. In this context, Gupta and Biherve (2007) reported that this typecast have reduced entrepreneurial intent of female students of management institutes. Ismail (2009) revealed that demographic factors having impact on entrepreneurship attitude are age, sex, education and work experience. Anisa, Vasilika, and Besa (2013) investigated entrepreneurship intention among university students in Albania. They studied university students' inclination for having their own business with reference to family business setting. The study focused on entrepreneurship mindset and motivation factors for setting own business. Sampling units of the study were fourth year students of three different universities of Albania. They suggested that Albanian universities should redesign their entrepreneurship education with focus on new developmental initiatives.

According to Mazura and Norasmah (2011), in Malaysia, higher education institutes are focusing on disseminating entrepreneurial knowledge to train 
future entrepreneurs. It helps in emerging effective entrepreneurs. Hence for enhancing entrepreneurship intentions in students, entrepreneurship education plays crucial role. Mohammed and Aparna (2011) studied Entrepreneurship Intentions of MBA Students in Hyderabad. The study emphasized on autonomy i.e. entrepreneurship self-efficacy of the students and found that in context of India, there are certain restrictions for entrepreneurial intents with reference to society due to risk and uncertain future. Santhi and Kumar (2011) reported that favorable economic policy environment supports organizations to achieve efficiencies in global market. According to them, entrepreneurship is significant to satisfy entrepreneurs' desires and also for the economic contribution and growth by generating new jobs.

A study was conducted by Bhandari (2006) to identify intention for entrepreneurship of the first year students. According to the study, desire to lead other people and luck have significant impact on tendency to start new venture. Bernstein and Carayannis (2011) concluded that autonomy leads to interest in entrepreneurship and in case of students, higher levels of autonomy indicated higher likelihood of success as an entrepreneur.

The research work is an attempt to examine driving factors for entrepreneurship intentions among students of selected universities of North- India. In this regard, objectives of the research study are as below: To identify the main driving factors for Entrepreneurship Intention of students and to study effect of specific demographic variables viz. Gender, University Type and Area Type on Autonomy Factor of Entrepreneurship Intention of students.

\section{Research Method}

The present study emphasized on analyzing Entrepreneurship Intention, with reference to students of selected universities of North-India. The present study is a descriptive research. Data were collected through self-designed structured close-ended questionnaire based on 5-point Likert Scale through convenient sampling. After validating, the final total sample size was 400. Factor Analysis, Correlation, ANOVA and t-Test were applied for data analysis using SPSS 21. Cronbach alpha was found to be 0.82 , indicating higher reliability of the data collection instrument (Questionnaire). The respondents were management and engineering students from government and private universities belonging to Metropolitan area \& Non-Metropolitan area, consisting of male and female students.

\section{Result and Discussion}

Factor-Analysis was applied to items related to Entrepreneurship Intention of the questionnaire. Factor analysis resulted in the four driving factors of Entrepreneurship Intention, which are: Factor 1: Autonomy (When an individual is inclined towards entrepreneurship for the sake of freedom of work); Factor 2: Need for Achievement (When an individual needs some resources to achieve purpose of entrepreneurship); Factor 3: Confidence in Support-system (When an individual have confidence in Government and other support-system and then works hard to achieve effectiveness); and Factor 4: Risk-Taking Ability (When an individual knows risks related to entrepreneurship and ready to take risk).

Correlation analysis was also carried out between Entrepreneurship Intention and its four factors. Results indicate that highest degree of correlation of Entrepreneurship Intention was found to be with Autonomy Factor (.839) then respectively in order with Need for Achievement Factor (.790), Risktaking Ability Factor (.722) and Confidence in Support-system Factor (.712). This order represents order of influence of concerned factor on Entrepreneurship Intention. As highest correlation is for the Autonomy Factor, hence the present study emphasized on Autonomy Factor of Entrepreneurship Intention.

\section{Analysis of Autonomy Factor of Entrepreneurship Intention}

Problem 1: Is Autonomy Factor of Entrepreneurship Intention a function of University type, Area and Gender?

$H_{l}$ : There is no significant effect of Gender on $\mathrm{Au}-$ tonomy Factor of Entrepreneurship Intention.

The null hypothesis is accepted $(F=1.662, p=.198)$

$\mathrm{H}_{2}$ : There is no significant effect of University Type on Autonomy Factor of Entrepreneurship Intention.

The null hypothesis is accepted $(F=2.631, p=.106)$

$H_{3}$ : There is no significant effect of Area on Autonomy Factor of Entrepreneurship Intention.

The null hypothesis is rejected $(F=18.131, p=.000)$

Hence, there is effect of Area (Metropolitan area and Non-Metropolitan area) on Autonomy Factor of Entrepreneurship Intention.

$H_{4}$ : Gender and University type do not interact in terms of Autonomy Factor of Entrepreneurship Intention.

The null hypothesis is accepted $(F=.718, p=.397)$ 
$H_{5}$ : Gender and Area do not interact in terms of Autonomy Factor of Entrepreneurship Intention.

The null hypothesis is accepted $(F=1.008, p=.316)$

$H_{6}$ : University type and Area do not interact in terms of Autonomy Factor of Entrepreneurship Intention.

The null hypothesis is accepted $(F=.057, p=.812)$

$H_{7}$ : Gender, University type and Area do not interact in terms of Autonomy Factor of Entrepreneurship Intention.

The null hypothesis is accepted $(F=3.566, p=.060)$

For the above results, ANOVA Table 1 is shown as follows:

Table 1

ANOVA Table: Tests of Between-Subjects Effects

\begin{tabular}{|c|c|c|c|c|c|}
\hline Source & $\begin{array}{l}\text { Type III } \\
\text { Sum of } \\
\text { Squares }\end{array}$ & df 1 & Mean Square & $F$ & Sig. \\
\hline $\begin{array}{l}\text { Corrected } \\
\text { Model }\end{array}$ & $512.525^{\mathrm{a}}$ & 7 & 73.218 & 3.345 & .002 \\
\hline Intercept & 390993.234 & 1 & 390993.234 & 17860.911 & .000 \\
\hline GENDER & 36.381 & 1 & 36.381 & 1.662 & .198 \\
\hline $\begin{array}{l}\text { UNIV_TYP } \\
\text { E }\end{array}$ & 57.586 & 1 & 57.586 & 2.631 & .106 \\
\hline AREA & 396.897 & 1 & 396.897 & 18.131 & .000 \\
\hline $\begin{array}{l}\text { GENDER * } \\
\text { UNIV_TYP } \\
\text { E }\end{array}$ & 15.728 & 1 & 15.728 & .718 & .397 \\
\hline $\begin{array}{l}\text { GENDER * } \\
\text { AREA }\end{array}$ & 22.076 & 1 & 22.076 & 1.008 & .316 \\
\hline $\begin{array}{l}\text { UNIV_TYP } \\
\text { E*AREA }\end{array}$ & 1.241 & 1 & 1.241 & .057 & .812 \\
\hline $\begin{array}{l}\text { GENDER * } \\
\text { UNIV_TYP } \\
\text { E*AREA }\end{array}$ & 78.055 & 1 & 78.055 & 3.566 & .060 \\
\hline $\begin{array}{l}\text { Error } \\
\text { Total } \\
\text { Corrected } \\
\text { Total } \\
\end{array}$ & $\begin{array}{r}8581.273 \\
432179.000 \\
9093.797\end{array}$ & $\begin{array}{l}392 \\
400 \\
399\end{array}$ & 21.891 & & \\
\hline
\end{tabular}

Problem 2: Do the students differ in terms of Autonomy Factor of Entrepreneurship Intention?

$H_{8}$ : Male students do not differ significantly from female students in terms of Autonomy Factor of Entrepreneurship Intention.

$$
\overline{\mathrm{X}}_{\text {MALE }}=32.68 \overline{\mathrm{X}}_{\text {MALE }} \approx \overline{\mathrm{X}}_{\text {FeMale }}
$$

The null hypothesis is accepted $(t=.659, p=.510)$

$H_{9}$ : Private university students do not differ significantly from Government university students in terms of Autonomy Factor of Entrepreneurship Intention.

$$
\begin{array}{|c|c|}
\overline{\mathrm{X}}_{\text {PRIV.UNIV. }}=32.36 & \overline{\mathrm{X}}_{\text {PRIV.UNIV. }} \approx \overline{\mathrm{X}}_{\text {GovT.UNIV. }} \\
{ }_{\text {GOVT.UNIV. }}=32.69 } }
\end{array}
$$

The null hypothesis is accepted $(t=-.680, p=.497)$
$H_{10}$ : Metropolitan area students do not differ significantly from Non-Metropolitan area students in terms of Autonomy Factor of Entrepreneurship Intention.

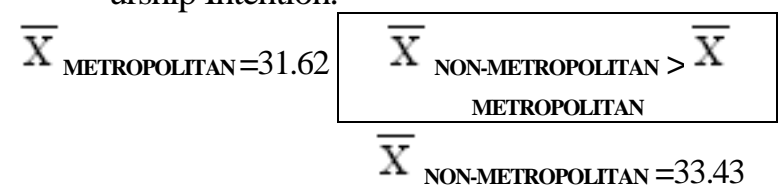

The null hypothesis is rejected $(t=-3.868, p=.000)$

$$
\overline{\mathrm{X}}_{\text {Metro.Male }=32.02} \frac{\overline{\mathrm{X}}_{\text {MEtro.Male }} \approx \overline{\mathrm{X}}_{\text {NON-METRO.Male }}}{\overline{\mathrm{X}}_{\text {NON-METRO.MALE }}=33.34}
$$

Hence, Metropolitan area students differ significantly from Non-Metropolitan area students in terms of Autonomy Factor of Entrepreneurship Intention. Non-Metropolitan area students are found to be more inclined towards Autonomy Factor than Metropolitan area students. It shows that Non-Metropolitan area students are having more Entrepreneurship Intention in terms of Autonomy.

$H_{11}$ : Metropolitan Male students do not differ significantly from Non-Metropolitan Male students in terms of Autonomy Factor of Entrepreneurship Intention.

The null hypothesis is accepted $(t=-1.931, p=.055)$

$H_{12}$ : Metropolitan Female students do not differ significantly from Non-Metropolitan Female students in terms of Autonomy Factor of Entrepreneurship Intention.

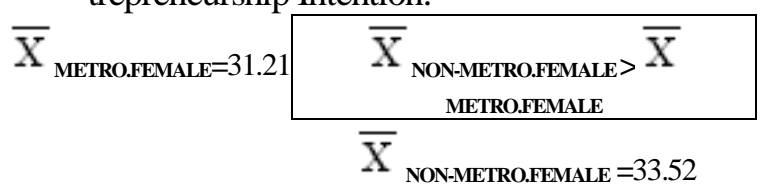

The null hypothesis is rejected $(t=-3.589, p=.000)$

Hence, Metropolitan Female students differ significantly from Non-Metropolitan Female students in terms of Autonomy Factor of Entrepreneurship Intention. Non-Metropolitan Female students are found to be more inclined towards Autonomy Factor than Metropolitan Female students. It shows that Non-Metropolitan Female students are having more Entrepreneurship Intention in terms of Autonomy.

$H_{13}$ : Private University Male students do not differ significantly from Government University Male students in terms of Autonomy Factor of Entrepreneurship Intention.

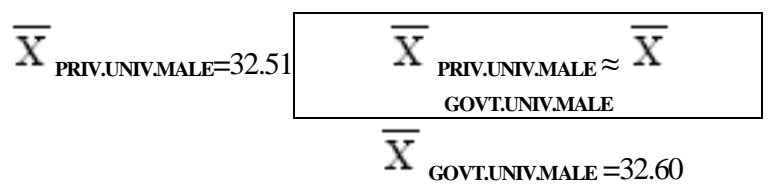

The null hypothesis is accepted $(t=-.135, p=.893)$ 
$H_{14}$ : Private University Female students do not differ significantly from Government University $\mathrm{Fe}$ male students in terms of Autonomy Factor of Entrepreneurship Intention.

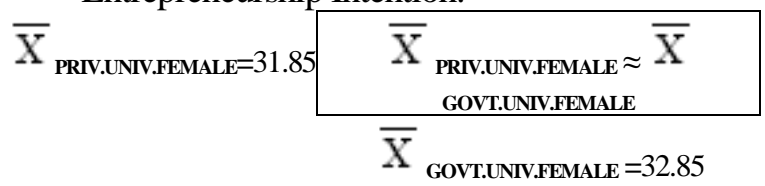

The null hypothesis is accepted $(t=1.392, p=.166)$

$H_{15}$ : Private University Male students do not differ significantly from Private University Female students in terms of Autonomy Factor of Entrepreneurship Intention.

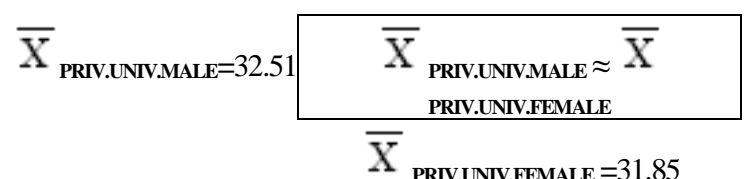

The null hypothesis is accepted $(t=.853, p=.395)$

$H_{16}$ : Government University Male students do not differ significantly from Government University Female students in terms of Autonomy Factor of Entrepreneurship Intention.

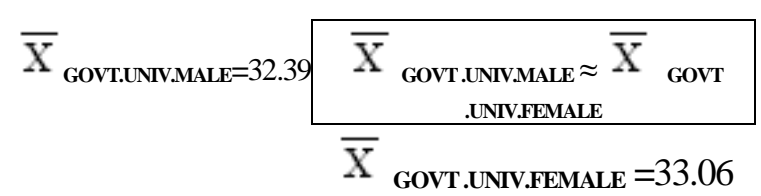

The null hypothesis is accepted $(t=1.015, p=.311)$

\section{Conclusions}

The research is intended to analyze mainly effect of Autonomy Factor on Entrepreneurship Intention of students of selected universities of North-India. NonMetropolitan area students were found to be more inclined towards Autonomy Factor than Metropolitan area students. It showed that Non-Metropolitan area students are having more Entrepreneurship Intention with reference to Autonomy. Also, Non-Metropolitan Female students were found to be more inclined towards Autonomy Factor than Metropolitan Female students. It showed that Non-Metropolitan Female students are having more Entrepreneurship Intention in terms of Autonomy.

The research findings on autonomy are supported by the study of Bernstein and Carayannis (2011), according to which autonomy is a major driver of entrepreneurship intention. The present study implied that Non-Metropolitan area students and especially Non-Metropolitan Female students are more inclined towards Entrepreneurship due to aspiration for Autonomy. Their aspiration for selfauthority, creativity and flexibility is more than Metropolitan area students. Bernstein and Carayannis
(2011) also reported that students having higher levels of autonomy have more probability to prosper as an entrepreneur. Probably due to inheritance and more job-opportunities, Metropolitan area students prefer joining some organization and have less aspiration for autonomy and entrepreneurship. It is an indication for more focus and better policy framework for NonMetropolitan area students and especially NonMetropolitan Female students, considering their Entrepreneurship Intention and for supporting them to start their business venture.

\section{References}

Anisa, K., Vasilika, K., \& Besa, S. (2013). Entrepreneurship characteristics amongst university students in Albania. European Scientific Journal, 9(16), 206-225.

Bernstein, A., \& Carayannis, E. G. (2011). Exploring the value proposition of the undergraduate entrepreneurship major and elective based on student's self-efficacy and outcome, USA, Proceedings.

Bhandari, N. C. (2006). Intention for entrepreneurship among students in India. Journal of Entrepreneurship, 15(2), 169-179.

Friedman, E. H., \& Triburelle, E. (2009). Examining a model of entrepreneurial intention among Malaysians. European Journal of Scientific Research, 3(2), 365-373.

Gibson, L. G., \& Gibson, R. A. (2010). Entrepreneurial attitudes of arts and business students. International Council for Small Business, June 24-27, 2010, Cincinnati, Ohio: Entrepreneurship, Bridging Global Boundaries.

Gupta, A. M., \& Biherve, E. A. (2007). Who wants to be an entrepreneur? A study of adolescents interested in a young enterprise scheme. Journal of Economic Psychology, 12(3), 465-478.

Henry, B. (2003). Entrepreneurship education in Kenya: A reality or plodding on? The First International Entrepreneurship Conference, 2324 April, Kenya.

Ismail, M. (2009). Entrepreneurial intentions among Malaysian students. International Journal of Business and Management, 4(10), 54-56.

Kuratko, D. F., \& Hodgetts, R. M. (2004). Entrepreneurship: Theory, process and practice. Ohio, US: Thomson Learning.

Mazura, M., \& Norasmah, O. (2011). CoBLAS: Inculcating entrepreneurship culture among higher education institutions' students. International Journal of Social Science and Humanity, 1(1), $86-91$ 
Mohammed, M., \& Aparna, M. P. (2011). Entrepreneurship intentions of mba students - A study in Hyderabad. Entrepreneurship Practice Review, 1(4), 20-37.
Santhi, N., \& Kumar, S. R. (2011). Entrepreneurship challenges and opportunities in India. Bonfring International Journal of Industrial Engineering and Management Science, 1(Special Issue), 14-16 